This item was submitted to Loughborough's Research Repository by the author.

Items in Figshare are protected by copyright, with all rights reserved, unless otherwise indicated.

\title{
Child's play and recreation in Dhaka City, Bangladesh
}

PLEASE CITE THE PUBLISHED VERSION

PUBLISHER

(c) Thomas Telford

VERSION

VoR (Version of Record)

LICENCE

CC BY-NC-ND 4.0

REPOSITORY RECORD

Ahmed, Afroza, and M. Sohail. 2019. "Child's Play and Recreation in Dhaka City, Bangladesh". figshare. https://hdl.handle.net/2134/4905. 
This item was submitted to Loughborough's Institutional Repository (https://dspace.lboro.ac.uk/) by the author and is made available under the following Creative Commons Licence conditions.

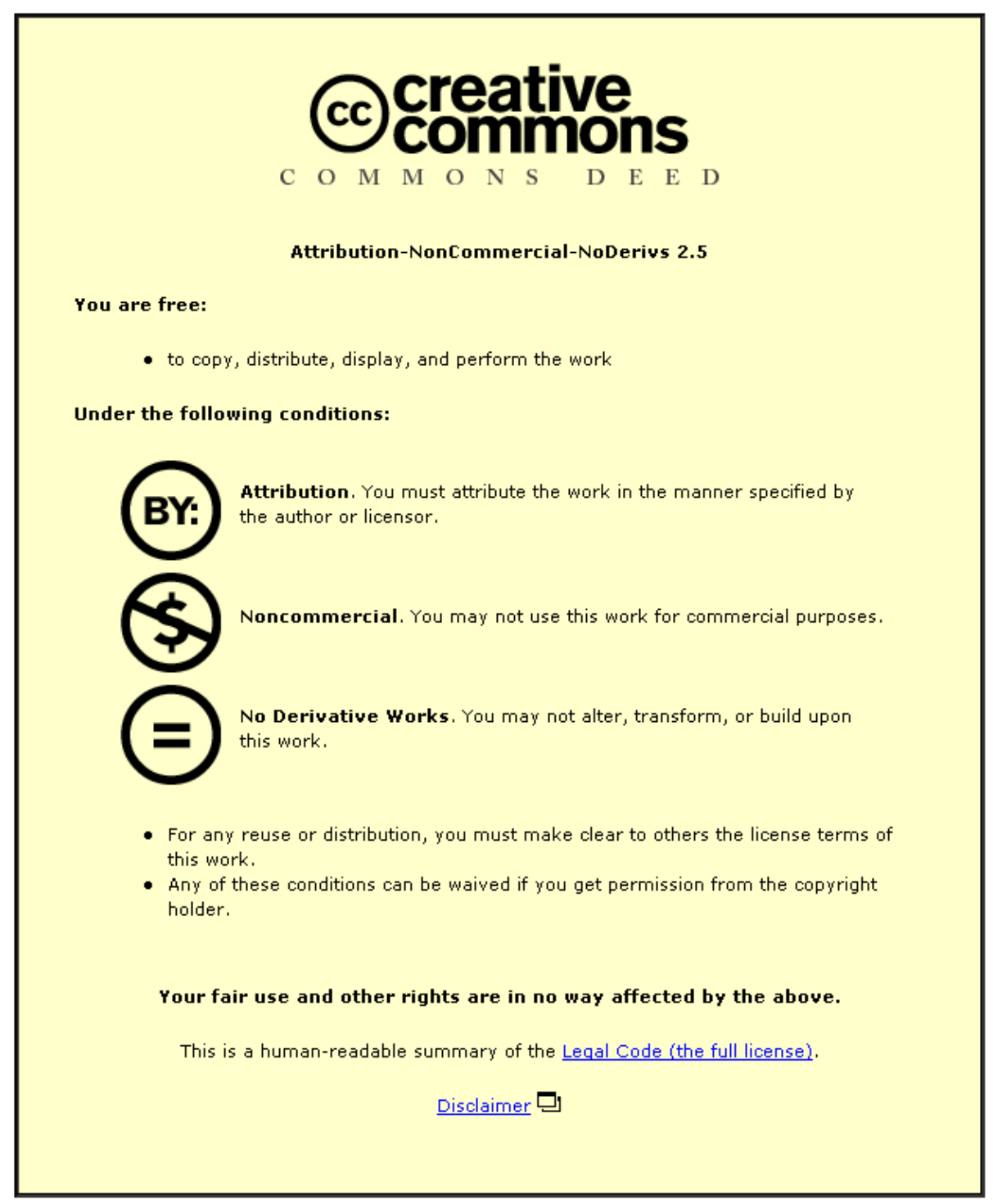

For the full text of this licence, please go to: http://creativecommons.org/licenses/by-nc-nd/2.5/ 


Proceedings of the Institution of
Civil Engineers
Municipal Engineer I6I
December 2008 Issue ME4
Pages $263-270$
doi: $10.1680 /$ muen.2008.161.4.263
Paper 700049
Received $06 / 1$ I I/2007
Accepted 07/08/2008
Keywords:
developing countries/social
impact/town \& city planning

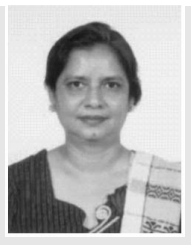

Afroza Ahmed
Research Student Loughborough University, UK

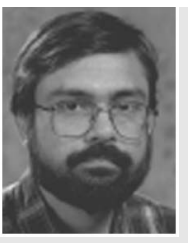

Muhammad Sohail Professor of Sustainable Infrastructure, Loughborough University, UK

\section{Child's play and recreation in Dhaka City, Bangladesh}

\section{A. Ahmed BArch, MURP and M. Sohail MSc, PhD, FASCE}

This paper is an attempt to take into account children's views and perceptions about their playing spaces, as a result of a study of playgrounds, parks and amusement parks in Dhaka City. It is quite evident that the so-called 'play and recreation facilities' provided by the authorities cater for only a fraction of the children in Dhaka City. Girls are almost totally excluded from using these facilities, while boys from high-income families and street children seldom use them. The main reasons for their inaccessibility to most children in Dhaka City are lack of security, poor maintenance and inadequate play facilities and accessories. It is recommended that further studies are undertaken on the existing provision of play spaces for children in order to understand better the impact of such spaces on their well being.

\section{INTRODUCTION}

The importance of play for a child's cognitive, social, physical and emotional development has been recognised by researchers. ${ }^{1,2}$ However, play facilities, formal or informal, are generally neglected in development agencies' research agendas. $^{3-5}$ This is surprising since the youth of a country represents its hope for development.

Children's right to play was first recognised as a basic right in the Convention on the Rights of the Child (CRC) adopted by the United Nations (UN) in 1989. Article 31 of the CRC stresses the responsibility of the state to ensure an enabling environment according to age and culture. The CRC also recognises children's right to play and leisure activities, which not only implies sufficient time for leisure, but also the provision of safe and appropriate space within communities. ${ }^{6}$

The realisation that children have a different perception from adults with regard to play spaces and their immediate environment was first indicated by the eminent urban planner Kevin Lynch $^{7}$ and has since been echoed by other contemporary researchers. For example, a number of public playgrounds were created in New York by the city authority to keep children off the streets and away from bad influences. However, it was revealed that only 20\% of the target children were attracted to play in these playgrounds: the children preferred to play closer to family, friends and neighbours rather than in isolated playgrounds. ${ }^{7}$
There is a need to formulate new policies, regulations and risk standards related to the design of children's living space, particularly their outdoor play and recreation space. ${ }^{8}$ Children are society's bridge to the future and it is vital to have their participation in urban planning. ${ }^{9}$ It is anticipated that relatively small changes in local play environments may have a big impact on children's lives. ${ }^{10}$

\section{LITERATURE REVIEW}

There is growing international recognition of the need actively to engage children and young people in urban planning and local governance. ${ }^{11}$ First, because they have the right to a voice in matters that concern them, as stated in article 12 of the CRC. Second, because young people are often experts on their local environment and so represent a key resource for urban planners. Third, lack of resources in urban areas (particularly in the developing country context) necessitates an approach that includes diverse stakeholders.

The imperative to include children and youth in planning, design and governance is officially recognised at international level.

(a) The UN CRC recognises that young people under 18 are entitled to express their views in all matters that concern them. ${ }^{12}$

(b) The Habitat Agenda states that special attention be paid to the participation of children and youth in shaping cities, towns and neighbourhoods in order to secure sustainable human settlements. ${ }^{13}$

(c) Agenda 21 of the Earth Summit indicates that children and youth must be involved in participatory processes to create more people-friendly, sustainable environments. ${ }^{14}$

There have been many efforts all over the world to involve children in the development of their own physical environments. Two of the more far-reaching initiatives in this regard are the child friendly city initiative (CFCI) by Unicef and Unesco's growing up in cities (GUIC) project. Including children in urban planning ${ }^{6,15-18}$

(a) fosters the social inclusion of children and youth in society

(b) encourages authorities to be accountable to the diverse needs of young people

(c) creates spaces for young people to express their views

(d) encourages young people to engage in shared decisionmaking with adults. 
Moreover, participation offers young people the chance to develop important decision-making and problem solving skills. ${ }^{19}$ Increasingly, research shows that young people who feel involved, safe, valued and connected are less likely to engage in risky behaviour patterns. ${ }^{10}$ The personal health benefits of meaningful participation of youth have been studied by the Canadian Centre of Excellence for Youth Engagement. ${ }^{1}$ Participation can mean that young people are less depressed, have higher self-esteem, are more physically active, obtain higher grades in school, and show a greater commitment to their friends, families and communities. ${ }^{20}$

Children's needs and perceptions regarding play and recreation are, in many cases, different from those of adults. Although children's needs and perceptions are not homogenous, a child will have a different perspective or mental view of events from adults due to their different stage of psychosocial development, different levels of socialisation and different life experience. ${ }^{21}$ There is danger in holding on to an adult-led, predetermined agenda because children's needs might be overlooked rather than addressed. It is, therefore, important to understand children's perceptions and needs with respect to outdoor play. However, developing the skills required to discover a child's real needs takes practice and expertise. ${ }^{22}$

Children's needs and perspectives will also vary according to gender and socio-economic background. ${ }^{23-25}$ Bangladesh is one of only four countries in the world where males outnumber females. The constitution of Bangladesh guarantees equal rights to all citizens, but gender discrimination is widespread in all spheres and at all levels. This is borne out by official statistics on health, nutrition and education, which indicate a higher death rate of girls than boys. Girls often have reduced access to education, especially in poor families, and are instead required to work in the home. There are several reasons that parents are reluctant to allow their daughters outside-many girls are expected to care for their siblings; parents fear for daughters' safety, as chastity and the reputation of unmarried girls are crucial factors that determine her value in the eyes of potential husbands and in-laws. ${ }^{26}$ Another obstacle for girls' play is negligence in identifying girls' play needs-girls' play is often viewed as playful preparation for motherhood. As a result, there has yet to be a serious effort to fulfil girls' play needs in terms of play space design and play equipment. ${ }^{27}$

\section{CONTEXT OF THE SURVEY}

According to a 2001 census, Bangladesh has a population of approximately 123 million with a population density of 834 persons $/ \mathrm{km}^{2}$. Dhaka City, the capital of Bangladesh, is experiencing extremely fast urbanisation and has one of the highest population densities in the world at 14939 persons $/ \mathrm{km}^{2}$. From a small town with a population of only 200000 people in 1947, Dhaka grew to a city of $4 \cdot 2$ million in 1987 and now has become a mega city of nearly 10 million. Children under 18 constitute about $48 \%$ of the population of Dhaka. Not so very long ago, Dhaka had an image of a city of greenery and water bodies, but within the last few decades Dhaka has turned into one of the most polluted and crowded cities in the world. Congestion, unplanned development and a rapidly increasing population have made Dhaka a concrete jungle with inadequate room for outdoor play or recreational facilities.
According to Unicef, 83 children die due to injuries every day in Bangladesh, 40 of them from drowning. ${ }^{28}$ Drowning of children in cities is mainly because of unfenced wells, ponds, rivers, and so on. On 26 December 2003, Bangladesh daily newspapers reported that five children were killed when they accidentally fell into a water tank while playing in the premises of a house under construction on the outskirts of Dhaka city. ${ }^{29,30}$ Accidental or unnatural death is the number one reason for child mortality in Bangladesh, accounting for more deaths than those related to acute respiratory infection or diarrhoea. Many of these could be avoided if safe facilities were provided to children to exercise their right to play. Such information provides evidence of the vulnerability of children that lack play space in their community. The risk associated with unsafe outdoor play is also a concern for guardians and carers. ${ }^{31}$

There are two types of space used for recreation in Dhaka City: open space for active recreation such as small play-lots, playing fields, playgrounds, sports grounds, stadiums and so on and open space for passive recreation-gardens, parks, parkways, green belts, botanical gardens, zoological gardens, and so on. This study considered the major play areas for children in Dhaka City to be playgrounds, parks and amusement parks. Although the number of amusement parks is not very significant in terms of capacity and area, it seems that these parks provide the only outdoor recreation space for the children from high- and middle-income groups and particularly for girls. This research focused on

(a) playgrounds-public outdoor areas used for recreation especially by children; usually equipped with facilities for recreation

(b) parks-enclosed pieces of ground in or near a city or town kept for ornament and recreation and maintained as public property

(c) amusement parks-public or commercially operated parks with various devices for entertainment (e.g. rides, water games, gardens) and usually booths for the sale of food and drink. The entry fee for these amusement parks is US\$5-12 (more than the daily wage of the poor in Dhaka).

Dhaka Metropolitan City is home to 148 playgrounds, 27 parks and 3 amusement parks. The ratio of outdoor play and recreation areas to the total area of Dhaka city is only 1:0.04, one of the lowest in the world (Table 1).

Open space in the city was approximately 1266 acres in 2004, a significant decrease from the 1916 acres in $1978 .{ }^{32}$ Due to the phenomenal increase in population over recent decades and the continuous encroachment into open space by the city corporation for profitable commercial land uses, space available for play and recreational activities has declined dramatically. ${ }^{33}$

\begin{tabular}{|lc|}
\hline Size: acre & $\begin{array}{c}\text { Proportion of } \\
\text { Dhaka's total area: \% }\end{array}$ \\
\hline $0.5-1 \cdot 0$ & 4 \\
$>1$ & $3 \cdot 8$ \\
$>14$ & $2 \cdot 8$ \\
\hline Table I. Size of parks and playgrounds \\
\hline
\end{tabular}




\section{METHODOLOGY}

It is recognised that children's perception and needs for their play space is different from that of adults, yet the majority of play space is designed by adults. ${ }^{34}$ Children's participation in the design of play space can bring more benefits and ensure more efficient utilisation of the space. The overall objective of this research is to give new directions and guidelines for the development of child friendly strategies and policies for play and recreation facilities in Dhaka City and other urban areas of Bangladesh. The main objectives of the study were to determine

(a) the existing condition of playgrounds, parks and amusement parks

(b) children's views about the existing condition, their satisfaction level and their opinions on improvements of the condition from a user's point of view.

The findings of this paper are based on a survey of users (children) of most of the playgrounds, parks and amusement parks in Dhaka City as well as parents' views on outdoor play and recreation facilities. Interviews using a precoded questionnaire were conducted at Dhaka playgrounds and parks. Children's views gained in the natural play environment made it possible to gain a more comprehensive understanding about their preferences, problems with existing conditions and an opportunity to verify some of the information through instant observations and discussions. Considering the usual play time for children, the surveys were conducted during late afternoon (16:00-18:00). The sample size of the survey was considered to about $10 \%$ of all the children who were present during that time. The age was asked of all major playground, park and amusement park users, particularly children aged between 5 and 18 years, during the data collection period.

In total, 499 children were interviewed in 102 playgrounds, 15 parks and all three amusement parks in Dhaka Metropolitan City during November-December 2004. Children aged 5-18 were surveyed from four major socio-economic groups (Tables 2-4)

(a) street children, that is, children living or working on the street

(b) children living in slums with their parents

(c) children from middle-income group: children from middleincome families, living in unplanned areas or in public housing estates/colony with monthly family income ranging from US\$80-350

\begin{tabular}{|lc|}
\hline & $\begin{array}{l}\text { Number of respondents } \\
\text { (\% of total) }\end{array}$ \\
\hline Children interviewed & 374 \\
Age 5-12 yr & $182(49 \%)$ \\
Age 13-18 yr & $192(51 \%)$ \\
Boys & $361(97 \%)$ \\
Girls & $13(3 \%)$ \\
Children from middle-income & $80 \%$ \\
bracket & $5 \%$ \\
Children from high-income bracket & $11 \%$ \\
Children from slums & $4 \%$ \\
Street children & \\
\hline Table 2. Socio-economic breakdown of respondents using \\
playgrounds
\end{tabular}

\begin{tabular}{|ll|}
\hline & $\begin{array}{l}\text { Number of respondents } \\
\text { (\% of total) }\end{array}$ \\
\hline Children interviewed & 84 \\
Age 5-12 yr & $44(53 \%)$ \\
Age 13-18 yr & $44(48 \%)$ \\
Boys & $72(85 \%)$ \\
Girls & $12(15 \%)$ \\
Children from middle-income & $70 \%$ \\
bracket & $2 \%$ \\
Children from high-income bracket & $11 \%$ \\
Children from slums & $16 \%$ \\
Street children & \\
\hline
\end{tabular}

Table 3. Socio-economic breakdown of respondents using parks

\begin{tabular}{|ll|}
\hline & $\begin{array}{l}\text { Number of respondents } \\
\text { (\% of total) }\end{array}$ \\
\hline Children interviewed & 41 \\
Age 5-12 yr & $27(66 \%)$ \\
Age 13-18 yr & $14(34 \%)$ \\
Boys & $49 \%$ \\
Girls & $51 \%$ \\
Children from middle-income & $32(78 \%)$ \\
bracket & $9(22 \%)$ \\
Children from high-income bracket & - \\
Children from slums & - \\
Street children & \\
\hline Table 4. Socio-economic breakdown of respondents using \\
amusement parks
\end{tabular}

(d) children from high-income group: children living in planned or other residential area with minimum family income of US\$350/month.

Key informant interviews were also conducted with planners, architects, playground and park managers, a child psychologist, real estate developers and representatives from Capital Development Authority (Rajuk), Urban Development Directorate (UDD), Unicef and Unesco.

\section{I. Playgrounds}

Most of the 148 playgrounds (Table 5) in Dhaka City vary in size from the size of a badminton court to the equivalent of a cricket or football pitch (55\% are larger than a football pitch). The physical conditions of the playgrounds are not always suitable for play due to, for example, uneven ground, lack of grass or a boundary wall or else the playgrounds are encroached by slums. In more than $60 \%$ of cases, the playgrounds were not well maintained; lack of proper rubbish collection facilities (18\%), dirt (11\%) and irregular mowing (11\%) were the three major problems observed in these playgrounds. Toilet facilities were

\begin{tabular}{lr}
\hline Owner & \\
\hline Authority of some institution & 64 \\
Community & 18 \\
Private organisation & 6 \\
Capital Development Authority & 4 \\
Other & 56 \\
Total & 148
\end{tabular}

Table 5. Number of playgrounds in Dhaka city differentiated by owner 
found in only 3\% of cases. Proper maintenance and satisfactory condition was observed in only a fifth of playgrounds. Noise (20\%), dust (18\%) refuse dumping (7\%) and grazing of cattle (2\%) were also found to be problems in some of the playgrounds.

\subsection{Parks}

There are 27 parks in the Dhaka metropolitan area, about half of which are maintained by Dhaka City Corporation (DCC). Rajuk, private and government organisations and others are responsible for the maintenance of the remainder. The two most common facilities found in parks were seating arrangements and walkways. Swings and slides were observed in about a third of the parks; and lights and toilet facilities were observed present in nine and eight parks respectively. Restaurants were found only in two cases. Trees and shaded areas were also found in most of the parks. Similarly to the playgrounds, uneven ground, indiscriminate disposal of rubbish, noise and lack of maintenance are the major problems in the majority of the parks.

\subsection{Amusement parks}

Most of the amusement parks in Dhaka City are owned by private organisations and are situated outside the DCC area. However, three amusement parks-Shishu Park (a children's park), Shishu Mela (children's fair) and Wonderland-are located in central Dhaka and are owned by DCC. Most amusement parks had paved walkways, seating arrangements, shelters, restaurants and toilet facilities (although poorly maintained).

\subsection{Informal play}

Informal play was observed in the streets of the colonies (public housing areas), at the entrance of access roads in the planned residential areas and in the alleys of unplanned residential areas. In most cases, children were found playing (mostly cricket) on the paved access roads, narrow streets or uneven grounds close to their houses (Figure 1). There was no maintenance of these informal play areas. Most of these areas were noisy, unclean, unfenced and littered with rubbish. Slum children and children from middle-income families were most likely to be found in these areas. Informal play is areas such as these is very common among the younger children of Dhaka City.

\subsection{Other play and recreation facilities}

Other than playgrounds, parks and amusement parks, children also reported visiting museums, theatres, the national parliament building, Lalbagh Fort, Ahsan Manjil (a palace) and various sporting facilities. Most of these facilities are owned by Rajuk or DCC. Children in Dhaka also enjoy playing video games. Video game shops are cramped (about 6-9 $\mathrm{m}^{2}$ ) and 8 to 17 children play at one time (Figure 2). Children living in slums and those of middle-income background were the predominant users of these facilities. Most of the video games shops are very noisy and situated in old Dhaka in unplanned residential areas.

\section{OUTDOOR PLAY AND RECREATION PATTERN OF CHILD USERS IN DHAKA CITY}

\section{I. Playgrounds}

The majority of the children (68\%) were found to come to the playground daily in the afternoon. About $80 \%$ children used the playgrounds for between one and three hours a day. Most children walk to the playground, often less than $800 \mathrm{~m}$,
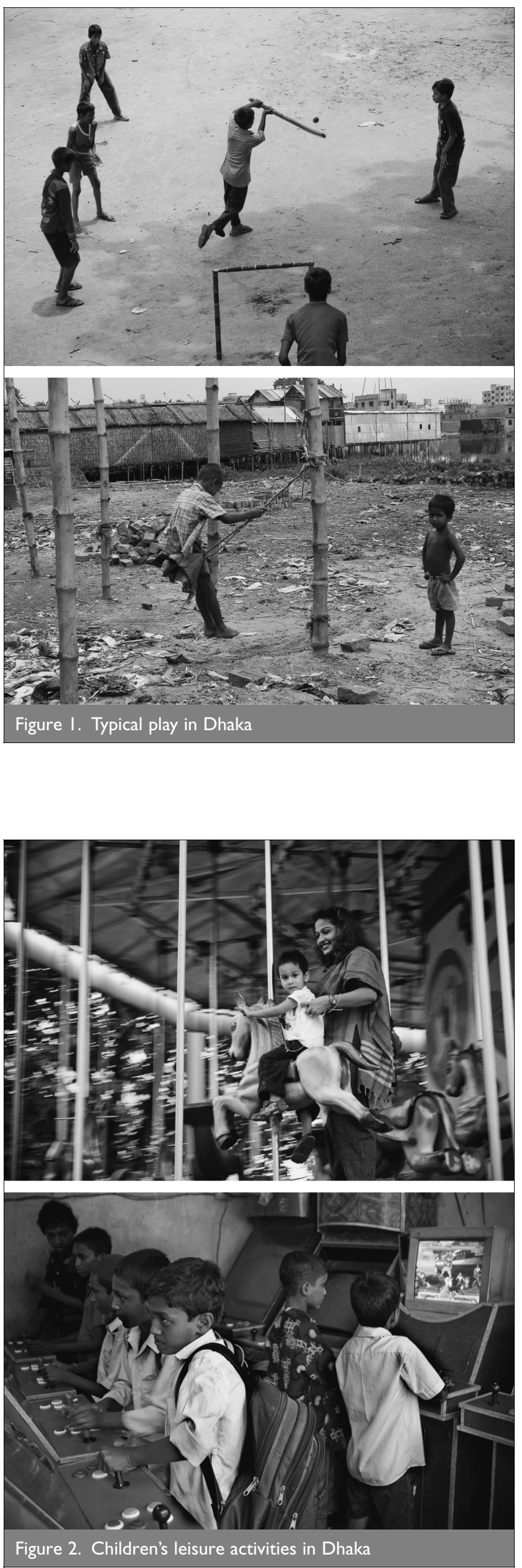


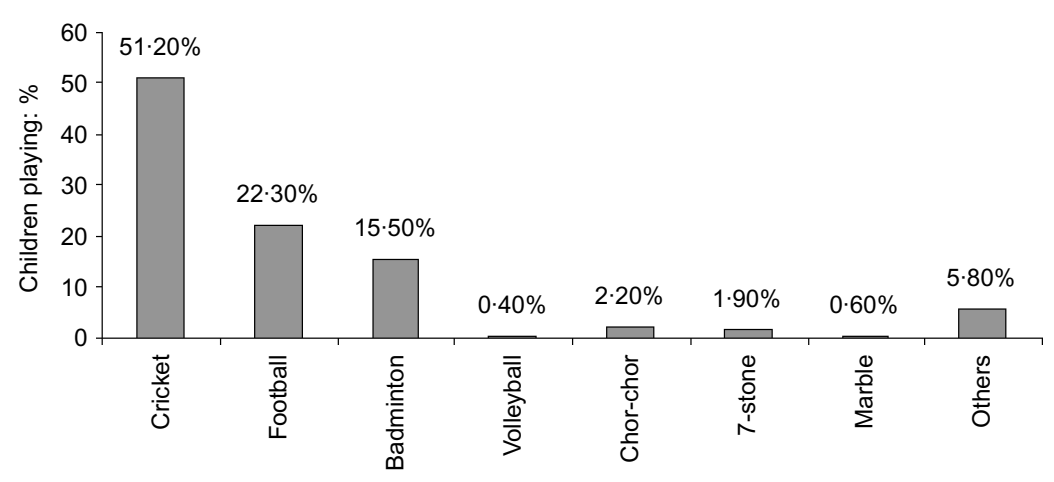

riding the trains, merrygo-round (Figure 1) or playing water games.

\section{CHILDREN'S VIEWS ON OUTDOOR PLAY AND RECREATION FACILITIES}

\subsection{Playgrounds}

On the whole, the children were satisfied with the shape and size of their playgrounds. The top three factors for dissatisfaction in playgrounds (Figure 5) were

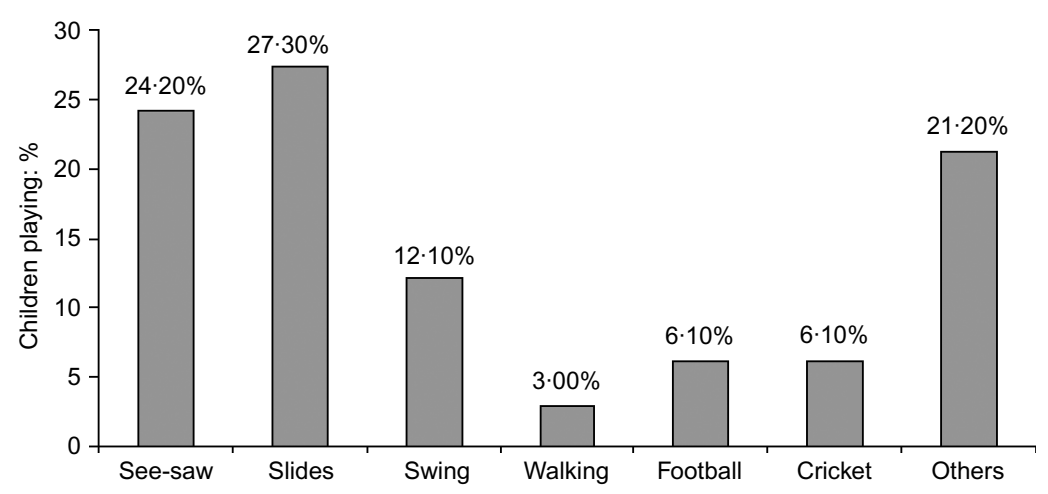

Figure 4. Play activities observed in parks

and therefore no travel costs are involved (and there is no entry fee for playgrounds). One-third of the children reported that their travel time was less than five minutes. Most children were observed playing cricket, football and badminton. Cricket and football are the two games played by boys of all socio-economic groups, whereas volleyball and badminton are mostly played by boys and girls from middle- and high-income groups. Hide and seek, 7-stone and marbles are also played, though mostly by slum and street children (Figure 3).

\subsection{Parks}

Half of the children interviewed came to the park every day. About 60\% visit the parks in the afternoon and morning. Being less than $800 \mathrm{~m}$ from the homes of about half the children, the majority walk to the parks. Playing on the slides (15\%) and cricket (14\%) are the major recreation for young children (5-12 yr). Among adolescents, strolling (20\%) and cricket (15\%) are the two main activities observed in parks. Girls are more likely to play on the swings and slides or go for a stroll, whereas boys are more likely to play cricket or stroll (Figure 4).

\subsection{Amusement parks}

Most children visit amusement parks only occasionally. About $44 \%$ of the children interviewed in the amusement parks were visiting for the first time. Half of the children spent three hours on average in the amusement parks. About one-third of children travelled by auto-rickshaw or car to visit these amusement parks (they are situated on the fringes of Dhaka City); most came from more than $8 \mathrm{~km}$ away. The average entry fee for the amusement park is Tk. 700-00 (\$10). Most spent between Tk. $50 \cdot 00-200 \cdot 00$ on travel costs. Most of the children were observed grass, free of cattle/animals and restrictions on

(a) poor rubbish collection (73\%)

(b) lack of drinking water (71\%)

(c) toilet facilities (70\%).

Most children wanted toilets (72\%), shelters (40\%) and slides $(38 \%)$ in their playground; good lighting was particularly important for adolescents. Street children cited clean and even ground, antisocial activities as the most essential physical elements for a good playground. The essential elements for slum children were size (large), restriction on cattle grazing, grass, and calm and quiet areas. Calm and quiet areas and even and clean ground were the most desirable elements in a good playground according to middle- and high-income children.

\subsection{Parks}

Close proximity to their house is the prime reason that children visit their local park. Their large size (12\%), good maintenance $(6 \%)$ and natural beauty $(6 \%)$ were also reasons mentioned by the children as to why they use parks. The majority of children using parks were satisfied with the condition of plants (80\%), walkways $(70 \%)$ and flowers (51\%). Cause of dissatisfaction were lack of drinking water (81\%), lack of adequate toilet facilities (76\%) and poor rubbish collection (61\%) (Figure 6). Other problems mentioned included noise, pollution from vehicles, anti-social behaviour, lack of shelter and poor security. The most important facilities for park users were found to be
(a) toilets (46\%)
(b) good lighting (37\%)
(c) shelter (11\%) (particularly for street and slum children).

\subsection{Amusement parks}

The main reasons for visiting amusement parks is availability of play facilities (25\%), good maintenance (25\%), attractive designs $(18 \%)$ and good information about the parks (18\%). Among amusement park users, the presence of trees and greenery (90\%), flowers (76\%), children's play facilities (76\%) and availability of drinking water were the major aspects of satisfaction; children 


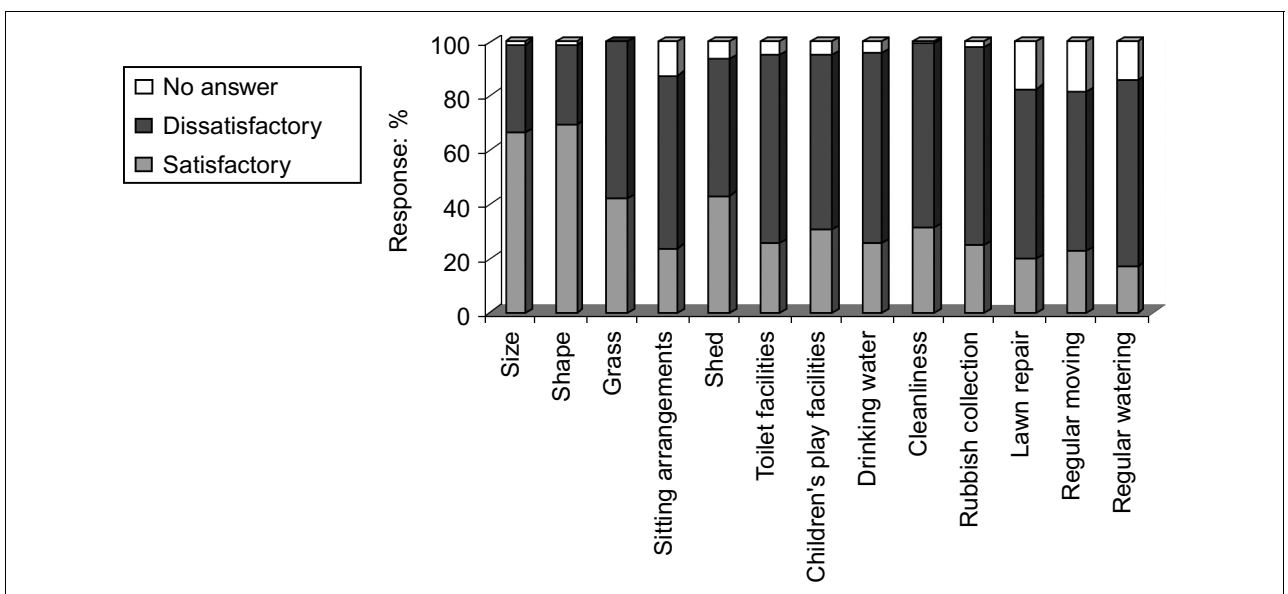

Figure 5. User satisfaction survey results: playgrounds

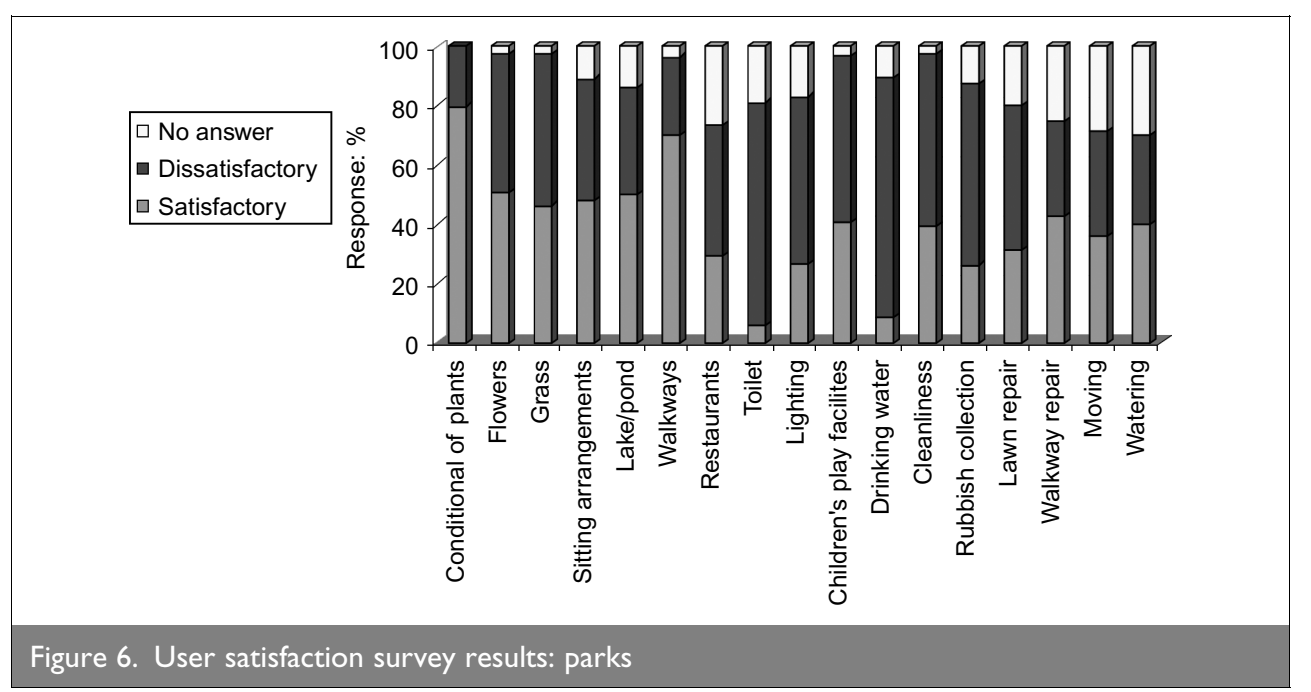

(c) $73 \%$ of the children wanted a playground less than $800 \mathrm{~m}$ from their house.

\subsection{Parks}

(a) As mentioned in Section 7.1, a different preference for combined park and playground schemes was noted between different age groups.

(b) Younger children expressed a preference for small parks within their communities; adolescents preferred bigger parks.

(c) The optimum distance between playground and house-irrespective of age or background-is under $800 \mathrm{~m}$.

\subsection{Amusement parks}

(a) About 29\% of the amusement park users recommended a combined amusement park and playground within the community; $24 \%$ recommended a small amusement park within the community.

using the park reported they were dissatisfied with the lighting (66\%), seating arrangements (61\%), walkways (58\%) and shelters (44\%). Toilets, good lighting, restaurants and shelters were determined as essential facilities for a good amusement park, from the point of view of users.

\section{CHILDREN'S RECOMMENDATIONS}

\section{I. Playgrounds}

(a) More than 50\% of children-irrespective of age or socioeconomic background-wanted to have a playground within their community. However, for adolescent boys, location was less important than size, and they would rather have bigger playgrounds that could be outside the community if space there is limited. A combined park and playground within the community was found to be desirable among younger children (age 5-15 yr); adolescents preferred separate but adjacent parks and playgrounds.

(b) It was found that about half of the children interviewed wanted a playground about the size of a football pitch; a quarter wanted a playground bigger than a football field; a fifth wanted a playground smaller than a badminton court (all those children were aged 5-12 yr). Adolescent boys wanted bigger sized playgrounds than did the younger children. (b) Most children using the amusement parks did not have a strong view on size.

(c) About 85\% children wanted to have an amusement park within $3 \cdot 2 \mathrm{~km}$ of their house.

\section{CONCLUSIONS}

This paper is an attempt to take into account children's views and perceptions about their playing spaces, which in many cases are different from those of adults. All the children interviewed for this research, irrespective of socio-economic group, were playing in playgrounds, parks, amusements parks or informal open spaces near their homes. However, the research found that children's needs and perceptions regarding play spaces varied with socio-economic background, age and gender.

It is quite evident that the so-called 'play and recreation facilities' provided by the concerned authorities cater for only a fraction of the children in Dhaka City. It was found that $97 \%$ of playground users and $85 \%$ of park users are boys. Girls are almost totally excluded from using these facilities. Adolescent girls living on the street and in slums have very little leisure time whereas adolescent girls from middle and high-income families have enough leisure time but do not have many opportunities for play and recreation; boys from the high-income group and children living on the streets seldom use the facilities. The highest 
numbers of users are children from middle-income families (80\% of playground users and 70\% of park users); conversely, small numbers of children from high-income families use playgrounds and parks (5\% of playground users and $2 \%$ of park users). Most children (78\%) using playgrounds lived less than $800 \mathrm{~m}$ away. According to the research, this close proximity to a playground within the community was considered desirable by most of the children. Perceptions regarding the most desirable size of playgrounds varied with children's age.

The major problems for playground users were absence of grass, uneven ground and inadequate toilet facilities. Dissatisfaction with parks stemmed from the absence of trees, greenery and shelter and limited space. Insufficient lighting and inadequate seating arrangements and walkways were found the most frequently reported problems in amusement parks. Inadequate play facilities and accessories were observed in 5\% of the playgrounds in Dhaka City. Lack of security was also cited as a key reason for not using playgrounds and parks in Dhaka City.

A little effort to listen to today's children could make a great contribution to the physical and mental development of our next generation. Planning around children's likings, fears and dreams about their immediate living environment is not always unattainable and unrealistic-even in the high-density conditions of cities in developing countries.

The provision of play and recreation facilities for the children of Dhaka City should be considered according to socio-economic group, age and gender. Recommendations to improve play spaces in Dhaka include the following.

(a) Institutionalise children's play and recreation in urban planning. There should be a separate department under DCC that is responsible for the formulation of policy based on needs assessments for play and recreation according to age, gender and socio-economic groups at ward level. The committee should comprise government, non-government organisations, Unicef, play associations and other community-based organisations. The authority should make an inventory of all the unused and under-utilised public and private open spaces and initiate action-research to make them more attractive for children's play and recreation purposes. Based on ward-level needs, the city authority should prepare a yearly plan; this should consider the provision of adequate financial support from government, establishment of new parks and playgrounds, improvement of landscape, security, regular maintenance and management aspects.

(b) Local level initiatives. Play associations at ward level are recommended for Dhaka City. Play associations should work in partnership with local authority/ward commissioners to identify gaps in local play services according to age, gender and socio-economic group and to develop a plan to provide these services. Informal play spaces should be well protected and fenced for younger children to play close to their homes.

(c) Capacity building of play and recreation professionals. Architects, landscape and interior designers, planners, teachers, coaches and recreation specialists should increase their knowledge of children's priorities for play.

(d) Play space incorporated into design. Measures should be taken to ensure that buildings of more than ten stories have space designated for cricket, basketball, badminton, and so on; see-saws, slides, swings and so forth should be provided for younger children.

(e) Maintenance. Lack of maintenance can make any area unattractive and under-used. Local authorities should budget for operation and maintenance.

(f) Attitudinal change. Parental fears (of traffic, strangers, drugs, bullying, dogs, etc.) are a key reason why children are not allowed to use playgrounds and parks. Efforts should be made by parents and communities (e.g. installation of proper boundary walls and security guards) to give children the opportunity to play in a safe environment. Lack of awareness and negative attitudes to the value of play are the underlying causes of most of the barriers to a child's rights to play. A concerted effort on the part of the government, organisations and communities should be made to promote the fact that play and learning are not competing ideologies.

(g) Accessibility and equity. The accessibility of parks and playgrounds to the different socio-economic groups of children living in Dhaka City should be monitored. This could be done using a GIS and should be considered for the design of recreational facilities within Dhaka City.

(h) Involving children in decision-making. Children can sensitise decision makers, urban officials and community leaders to their needs and priorities for play and recreation facilities through workshops, demonstrations, action research and public events. Such awareness-raising can bring children and parents together with city officials and community leaders to discuss issues and draft action plans. Unicef should play a vital role for this purpose.

Planners and decision makers should apply a child friendly lens to policy affecting children-particularly in the design and planning of playgrounds, parks and amusement parks. Play is not just about providing safe playgrounds and parks for children. It is fundamental to protecting their rights to be free to discover and explore their physical and social world on their own terms. It is hoped that these recommendations will make Dhaka, and cities in general, more child-friendly, ultimately producing

(a) happier children (with increased self-esteem and social skills)

(b) better play areas, parks and green open spaces in residential areas as well as for street children

(c) security/safety

(d) greater social inclusion (increased stakeholder involvement, decreased marginalisation)

(e) strengthened democracy (greater youth input in decision making and governance)

$(f)$ safer informal play spaces.

\section{REFERENCES}

1. Canadian Centre of Excellence for Youth Engagement. Youth Engagement and Health Outcomes: Is There a Link? See http://www.tgmag.ca/centres/litrev2.htm for further details. Accessed 03/04/2007.

2. ChaWla L. Growing up in an Urbanizing World. Earthscan, London, 2002.

3. SAVE the Children. Participation-Spice it Up! Practical Tools for Engaging Children and Young People in Planning and Consultations. Save the Children UK, London, 2003. 
4. World VISION. Child Participation: Challenges of

Empowerment. World Vision, 2002, pp. 1-28.

5. International Institute for Child Rights and Development. Children As Partners. Annotated Bibliography. IICRD, Victoria, 2004.

6. Bartlett S., Hart R., Satterthwaite D., de la Barra X. and Missair A. Cities for Children: Children's Rights, Poverty and Urban Management. Earthscan, London, 1999.

7. Lynch K. Growing Up in Cities. MIT Press, Cambridge, MA, 1977.

8. DRISKell D. Creating Better Cities with Children and Youth: A Manual for Participation. Earthscan/UNESCO, London/Paris, 2002.

9. JUKES A. Children's participation in urban design. Urban Design Quarterly, 2004, 89, 32-33.

10. Cook P., Blanchett-Cohen N. and Hart R. Children as Partners: Child Participation Promoting Social Change. IICRD, Victoria, 2004. See www.uvic.ca/iicrd for further details. Accessed 28/09/2008.

11. The participation charter: a vision for giving children and young people a say in the decisions that affect them. Children Now, 2006, 7 Jun, 20-22.

12. See www.unicef.org/crc/crc.htm

13. See www.unhabitat.org/unchs/english/hagenda/

14. See www.un.org/esa/sustdev/documents/agenda21/ index.htm

15. HART R. Children's Participation-from Tokenism to Citizenship. UNICEF International Child Development Centre, Florence, 1992.

16. Hart R. A. Children's Participation: The Theory and Practice of Involving Young Citizens in Community Development and Environmental Care. Earthscan, London, 1999.

17. Auriat N., Miljeteig P. and Chawla L. Children's Participation-Evaluating Effectiveness. International Institute for Environment and Development, London, 2001.

18. Cook P. and Blanchet-Cohen N. Creative Tools: Civic Engagement of Young People. IICRD, Centre for Global Studies, University of Victoria, Growing up in Cities Canada, 2006.
19. Checkoway B., Richards-Schuster K., Abdullah S., Aragon M., Facio E., Figueroa L., Reddy E. and Welsh M. Young people as competent citizens. Community Development Journal, 2003, 28, No. 4, 298-309.

20. Dallape F. Urban children, a challenge and an opportunity. Childhood: A Global Journal of Child Research, 1996, 3, No. 2, 283-294.

21. ERIKSon E. H. Identity and the Life Cycle. W. W. Norton, New York, 1994.

22. Freeman C. Planning with Children for Better Communities: The Challenge to Professionals. Policy Press, Bristol, 1999.

23. KaRSTEN L. Children's use of public space; the gendered world of the playground. Childhood, 2003, 10, No. 4, 457-473.

24. PANTER-Brick C. Street children, human rights and public health. Annual Review of Anthropology, 2002, 31, 147-171.

25. Harper C., Marcus R. and Moore K. Enduring poverty and the conditions of childhood: life course and intergenerational poverty transmissions. World Development, 2003, 31, No. 3, 535-554.

26. Asian Development Bank. Women in Bangladesh: Country Briefing Paper Programs Department (West). ADB, 2001.

27. Gagen E. A. An example to all of us: child development and identity construction in early 20th century playgrounds. Environment and Planning, 2000, 32, No. 4, 599-616.

28. Innocenti Research Centre Unicef. Child Mortality and Injury in Asia. IRC, Florence, 2007, Working paper IWP-2007-04.

29. Daily Star, 2004.

30. Bangladesh Observer, 2003.

31. Conticini A. Urban Livelihoods from children perspectives: protecting and promoting assets on the streets of Dhaka. Environment and Urbanisation, 2005, 17, No. 2, 69-81.

32. Mahbub-Un Nabi, 1978

33. The Daily Star, 2007

34. Aнmed A. and SoHAIL M. Children's perception on their living spaces in Dhaka City: a qualitative overview. Proceedings of XXII World Congress of Architecture, Istanbul, 2005, 17pp.

\section{What do you think?}

To comment on this paper, please email up to 500 words to the editor at journals@ice.org.uk

Proceedings journals rely entirely on contributions sent in by civil engineers and related professionals, academics and students. Papers should be 2000-5000 words long, with adequate illustrations and references. Please visit www.thomastelford.com/journals for author guidelines and further details. 